\title{
ANALYSIS OF LAND COVER CHANGES IN THE BONSA CATCHMENT, ANKOBRA BASIN, GHANA
}

\author{
ADUAH, M. S. - WARBURTON, M. L. - JEWITT, G. \\ Centre for Water Resources Research, University of KwaZulu-Natal, PBAG x01, 3209, \\ Scottsville, Pietermaritzburg, South Africa. \\ (phone:+27-033-260-5678; fax: +27-033-260-5818) \\ *Corresponding author \\ e-mail: msaduah@umat.edu.gh
}

(Received $1^{\text {st }}$ Dec 2014; Accepted $19^{\text {th }}$ Feb 2015)

\begin{abstract}
Multi-temporal land cover changes in the Bonsa catchment of the Ankobra Basin in Ghana were determined using four satellite images from 1986, 1991, 2002 and 2011. The results indicate that evergreen forest is the largest class occupying an area of 68\% in 1986, 62\% in 1991, 50\% in 2002 and $51 \%$ in 2011 and during the past 26 years, the largest land cover change has been the conversion of evergreen and secondary forests to shrubs/farms, mining areas and settlements. During this period, mining areas increased over two-fold, while settlements and shrubs/farms increased more than three and four-fold, respectively. This resulted in increasing annual deforestation rate of $0.33 \%$ between 1986 and 1991, $0.70 \%$ between 1991 and 2002 and $2 \%$ between 2002 and 2011. The results suggests that the drivers of the land cover changes in the Bonsa catchment, are both local and global and include, international trade, local population growth, agriculture extensification and urbanization. The identified land cover changes have the potential to impact negatively on the hydrological regimes of the Bonsa River and the local communities by leading to flooding, soil erosion and the siltation and pollution of the river during peak seasons and the scarcity of water during dry seasons. Therefore, the maps and statistics generated can be applied to assess the impacts of the land use changes on the local hydrology and provide a better basis for future land use planning. Through these findings the importance of multi-temporal analysis of satellite imagery for planning in data poor regions is highlighted.
\end{abstract}

Keywords: Bonsa catchment, Ghana, hydrological regimes, land cover change, multi-temporal analysis

\section{Introduction}

Land cover/land use changes occur by the alteration of the natural landscape through both anthropogenic activities and natural processes (Coppin et al., 2004; Hu et al., 2005). Natural causes include volcanoes, storm surges, floods, droughts, earthquakes and wildfires, while anthropogenic land cover/land use changes are influenced mainly by socio-economic drivers such as population growth, rural-urban migration, immigration, urbanization, government policy and economic development (Lambin et al., 2003; Cohen, 2004; D'Orgeval and Polcher, 2008). These changes in land use, in turn impact the hydrological responses of a catchment by altering the partitioning of precipitation into different components of the hydrological cycle, such as interception, infiltration, runoff, evapotranspiration and groundwater recharge rate (Costa et al., 2003; D'Orgeval and Polcher, 2008), as well as influencing water quality (Rogers, 1994; Randolph, 2012). To predict and manage the impacts of land cover/land use changes on hydrology, it is imperative to understand the land cover/land use change processes, the rates and possible causes of the changes. Satellite sensors, with their wide spatial and synoptic coverage over large areas, can provide spatially continuous and consistent data, which can be analysed to derive land cover maps and change statistics 
(Foody, 2002), required for effective land use planning and water resources management in a catchment. Such land cover maps and change statistics can be derived through the process of change detection and land cover mapping (Song et al., 2001).

Land cover/land use change detection is the process of categorizing differences in the state of the land cover by mapping it at different times over a period (Lambin and Ehrlich, 1997). The analysis of satellite images to detect land cover/land use changes is, based on the assumption that the recorded electromagnetic radiation, which is the basis of categorizing land covers, is altered as the land cover/land use of the same geographic area changes (Lambin and Ehrlich, 1997; Abuelgasim et al., 1999). Change detection techniques can be categorized as algebraic, transformation, classification and visual analysis techniques (Coppin et al., 2004). Algebraic based methods include image differencing, image regression, image ratioing, normalised difference vegetation index (NDVI) differencing and change vector analysis (CVA) (Braimoh and Vlek, 2004; Coppin et al., 2004), while those in the transformation category include multi-date Principal Component Analysis (PCA), Kauth-Thomas (KT) and Chi-square transformations (Coppin et al., 2004). The classification methods consist of post-classification comparison, multi-date classification, spectral-temporal combined analysis and unsupervised change detection (Coppin et al., 2004; Braimoh and Vlek, 2005). Algebraic and transformation methods are suitable for detecting continuous changes, while classification methods are effective for categorical changes (Abuelgasim et al., 1999), but depend on the accurate geometric registration and classification of individual images (Coppin et al., 2004). Continuous changes refer to changes in the concentration or amount of an attribute (e.g. biomass and the leaf area index of a forest), while categorical changes are the conversion of one land cover type to another (e.g. evergreen forest to a mining area). Visual analysis techniques ( $\mathrm{Lu}$ et al., 2004) are primarily based on the visual interpretation of aerial photographs and high resolution images.

Image classification techniques, using either unsupervised or supervised classification (Campbell, 2002; Foody, 2002; Richards and Jia, 2006) can be used to implement the post-classification comparison methods. However, supervised classification systems have found a wider usage, because it is possible to create specific thematic classes (Campbell, 2002) with respect to the objectives of a study. Supervised classification systems can be grouped as either parametric or non-parametric methods. The parametric methods include maximum likelihood classification (MLC) (Campbell, 2002; Richards and Jia, 2006), fuzzy-set classifiers (Suresh Babu and Viswanath, 2009; Stavrakoudis et al., 2011), sub-pixel classifiers (Verhoeye and De Wulf, 2002; Frazier and Wang, 2011), spectral mixture analysis (Nichol et al., 2010; Youngentob et al., 2011) and object-oriented classifiers (Geneletti and Gorte, 2003; Platt and Rapoza, 2008). The non-parametric methods include artificial neural networks (ANN) (Atkinson and Tatnall, 1997; Abuelgasim et al., 1999; Laurin et al., 2013), decision tree and support vector machines (Huang et al., 2002). In terms of image classification accuracies, literature shows that the ANN and the MLC algorithms perform better than the other methods (Atkinson and Tatnall, 1997; Abuelgasim et al., 1999; Laurin et al., 2013). Nevertheless, the application of the statistically-based MLC algorithm is more common, as it is widely accessible in much remote sensing software and it is considered easier to implement, compared to ANN (Richards and Jia, 2006; Lu and Weng, 2007).

When applying methods of land cover change detection, the advantages vary, depending on the techniques employed and the nature of the change under investigation. 
According to Coppin et al. (2004) among others, complementary use of more than one technique has the potential to generate the best results. Nonetheless, available literature indicates that post-classification comparison techniques are preferred by many researchers (Braimoh and Vlek, 2004; Aduah and Aabeyir, 2012; Kumi-Boateng et al., 2012; Wasige et al., 2013). It is advantageous to use post-classification comparison methods because individual images are classified separately, which minimizes the requirement to conduct absolute radiometric corrections and the techniques also produce change matrices (Coppin et al., 2004), which are needed to identify change trajectories. The methods are also simple and accessible in a variety of software and can be used to detect categorical land cover changes.

Previuos studies (Kusimi, 2008; Schueler et al., 2011; Kumi-Boateng et al., 2012) within the Ankobra River basin of the Western region of Ghana indicates that there is extensive deforestation, as a result of increasing urbanisation, mining and farming. Even though these studies analysed land cover changes for the Wassa West District within the Ankobra River basin (Kusimi, 2008; Schueler et al., 2011; Kumi-Boateng et al., 2012), none covered the entire Bonsa sub-catchment nor applied the results of the studies to project potential future land use changes, as well as assessing the impacts of the land use changes on catchment hydrology. As a first stage in projecting potential future land use changes and assesing their impacts on Bonsa catchment hydrology, a more recent and multi-temporal land cover information for the entire catchment is needed. In this study, the post-classification comparison and the MLC methods were selected to map and to detect the multi-temporal land cover changes in the Bonsa sub-catchment of the Ankobra River basin in Ghana, West Africa, over a period of 26 years (i.e 1986 to 2011). The study seeks to determine the rates of change in the land cover types, the transitions between different land cover types and to elicit an understanding of the possible drivers of the land cover changes and their impacts on the environment.

\section{Methodology}

\section{Description of Study Area}

The Bonsa catchment, a sub-catchment of the Ankobra River basin in Ghana, West Africa (Figure 1), is located between longitudes $1^{\circ} 41^{\prime}$ and $2^{\circ} 13^{\prime}$ West and latitudes $5^{\circ} 4^{\prime}$ and $5^{\circ} 43^{\prime}$ North and it straddles the intersection of four administrative districts, namely: Twifo Heman Lower Denkyira to the north, Tarkwa Nsuaem and the PresteaHuni Valley to the west and Mpohor Wassa East to the east. The catchment has a generally low relief, with the elevations ranging between 30 and $340 \mathrm{~m}$ above mean sea level and it drains an area of $1482 \mathrm{~km}^{2}$. The rainfall regime is bimodal, with the peak season between February and July and the minor season between August and November. The rainfall ranges between $1578 \mathrm{~mm}$ and $1982 \mathrm{~mm}$ per annum and the annual average minimum and maximum temperatures are $22^{\circ} \mathrm{C}$ and $32^{\circ} \mathrm{C}$, respectively. Predominant land cover consists of thick evergreen and secondary forests, with scattered shrubs and farms. The basin's geology is characterized by Birimian and Tarkwaian rock systems (Akabzaa et al., 2009), while the soil is composed mostly of Ferric Acrisols, according the Food and Agricultural Organisations'(FAO) soil classification system and forest oxysols (Dwomo and Dedzoe, 2010), according to the Ghana soil classification system. Major economic activities in the catchment include open-pit gold mining, rubber cultivation and smallscale cocoa and food crop production. 


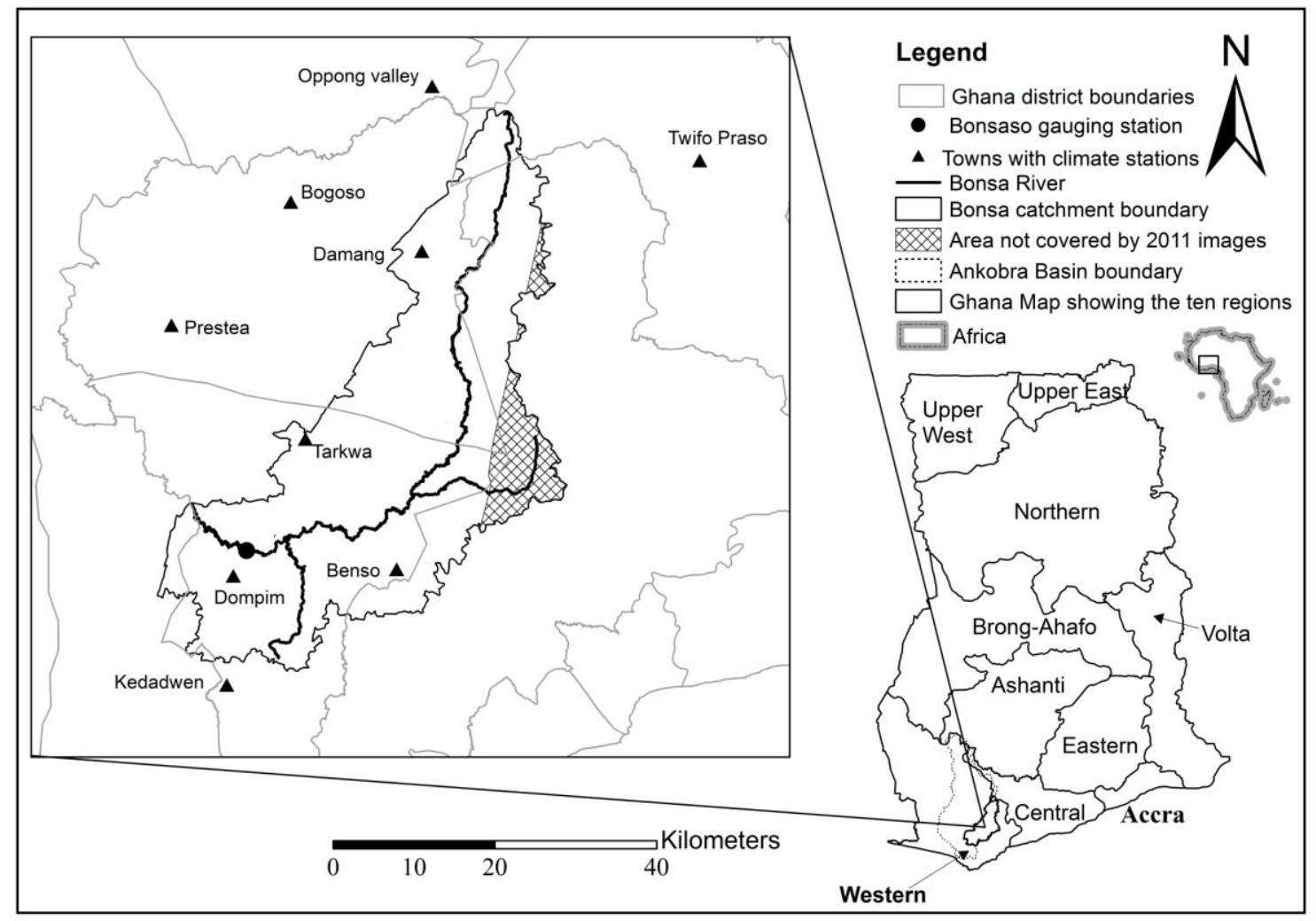

Figure 1. Map of Bonsa catchment, a sub-catchment of the Ankobra River basin in Ghana, West Africa

\section{Data Acquisition}

Data used for the study included two digital topographic maps obtained from the Survey of Ghana (SOG). One of the maps is part of the SOG's 1:5 0000 series topographic maps produced in 1974 for the whole country, while the other is a 1:5000 topographic and detail map (produced in 2003) covering only the urban area of Tarkwa. Four satellite images covering the period 1986 to 2011 were also acquired from the United States Geological Survey (USGS) and the European Space Agency (ESA) (Table 1).

Table 1. Satellite images used for the study

\begin{tabular}{lcccccc}
\hline Sensor & No. bands & $\begin{array}{c}\text { Path/row } \\
\text { orbit/frame }\end{array}$ & No. scenes & $\begin{array}{c}\text { Spatial } \\
\text { resolution }(\mathbf{m})\end{array}$ & $\begin{array}{c}\text { Acquisition } \\
\text { date }\end{array}$ & Source \\
\hline Landsat TM/ETM+ & 7,8 & $194 / 056$ & 3 & 30,60 & $12 / 1986$, & USGS \\
& & & & $01 / 1991$, & \\
& & & & & $01 / 2002$ & \\
\hline ALOS AVNIR-2 & 4 & $26495 / 3490$, & 2 & 10 & $01 / 2011$ & $\begin{array}{c}\text { ESA category 1 proposal } \\
\text { (Third party mission } \\
\text { data) }\end{array}$ \\
\hline
\end{tabular}

In selecting the satellite images, near-anniversary image acquisition dates were selected to minimize seasonal vegetation differences. Fieldwork was conducted between July and August 2013 to collect ground truth data for image classification. The field data 
collection was based on an unsupervised classified map of the 2011 satellite images. In order to obtain information on the land cover for the historical images, the local knowledge of the author and that of some inhabitants of the sites visited, was applied, as well as the SOG topographic map for 2003.

\section{Image Pre-processing}

Errors in mapping land cover/land use changes can be reduced by performing image pre-processing before classification and change detection methods are applied. There are two main types of image pre-processing: geometric and radiometric corrections (Campbell, 2002; Narumalani et al., 2002; Richards and Jia, 2006). The geometric distortions resulting from sensor and platform errors, as well as the rotation of the Earth in relation to the sensor, are corrected by image registration. Geometric correction converts the satellite image geometry to real world coordinate and projection systems (Narumalani et al., 2002; Lu and Weng, 2007), to enable the comparison of two or more images, the extraction of information for use in a Geographic Information System (GIS) and to overlay images with maps from different sources. Radiometric correction, on the other hand, corrects for the effects of the atmosphere on satellite images (Campbell, 2002). The objective of radiometric correction in change detection is to ensure that available images are compared on the basis of similar radiometric properties (Coppin et al., 2004). Image pre-processing in this study consisted of only geometric correction. All the images had been geo-referenced to the UTM WGS84 Zone 30 North projection by the data suppliers, but they did not match with the geo-referenced topographic map of the study area. Hence each of the images was geometrically corrected, using the study area topographic map as a reference. The high resolution Advanced Visible and Near Infrared Radiometer Type 2 images of the Advanced Land Observation Satellite system (ALOS AVNIR-2) were first geometrically corrected after which the rest of the images were co-registered to them. Haze removal was not executed, because available algorithms distorted the images and reduced their quality. However, haze was not considered problematic since the change detection technique adopted was post-classification comparison, which relies on classified individual images. As the Bonsa catchment was the area of interest for the study, images were clipped, based on the catchment boundary (Figure 1).

\section{Image Classification and Accuracy Assessment}

Image classification was conducted by generating spectral signatures, using training samples created for each satellite image. The training samples were created by randomly selecting $70 \%$ of the sample class data for each satellite image. Six thematic classes were selected to represent the land cover of the Bonsa catchment, using the USGS's land cover classification scheme for Landsat data (Jensen, 2000). The classes used are secondary forests, water, evergreen forests, settlements, shrubs/farms and mining areas (Table 2). After creating the spectral signatures, the separability of the thematic classes was checked using the Jefferies-Matusita's matrices (Richards and Jia, 2006), and finally, the MLC algorithm was used to classify all the images using the generated spectral signatures. Since the ALOS AVNIR-2 images covered only $92 \%$ of the Bonsa Catchment, a strip of a 2009 SLC-off Landsat image was used to map the remaining (Figure 1) and it was merged with the land cover data from ALOS AVNIR-2 images to produce land cover data for 2011. It was observed from a field visit that the 
study area not covered by the 2011 images was part of a protected forest reserve (evergreen forest area as at January 2014). Hence in the absence of a current satellite image for the area, it was reasonable to map its land cover using the 2009 image, which depicts the area as evergreen forest.

Table 2. Land cover classification Nomenclature

\begin{tabular}{|c|c|c|}
\hline Land cover & Description & Photo \\
\hline Water & $\begin{array}{l}\text { water courses, } \\
\text { ponds/flooded } \\
\text { mine pits and rivers }\end{array}$ & 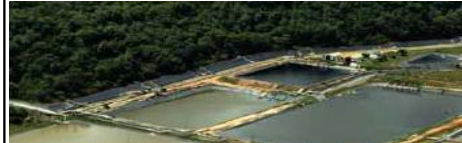 \\
\hline Shrubs/farms & $\begin{array}{l}\text { short tree species } \\
\text { and non-tree vegetation } \\
\text { such as herbs, grasses } \\
\text { and farms (cocoa, palm, plantain, } \\
\text { cassava, maize), recently } \\
\text { cleared forests }\end{array}$ & \\
\hline Evergreen forest & $\begin{array}{l}\text { tall trees including } \\
\text { indigenous species } \\
\text { and mature rubber } \\
\text { located mostly in } \\
\text { forest reserves } \\
\text { and plantation farms } \\
\end{array}$ & \\
\hline Secondary forest & $\begin{array}{l}\text { degraded/re-growth } \\
\text { forest and tree crops } \\
\text { (cocoa, palm) and rubber } \\
\text { with open canopy }\end{array}$ & 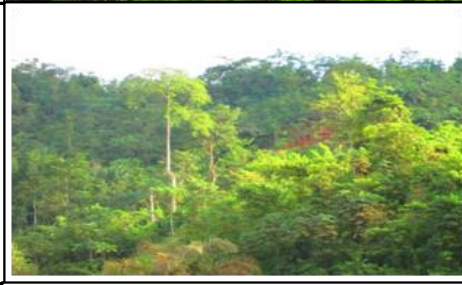 \\
\hline Settlement & $\begin{array}{l}\text { urban areas, villages, } \\
\text { paved/unpaved roads, } \\
\text { car/lorry parks, } \\
\text { bare lands, playing fields }\end{array}$ & 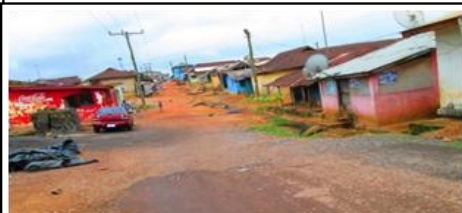 \\
\hline Mining areas & $\begin{array}{l}\text { areas where open } \\
\text { cast/surface mining } \\
\text { has taken place and mining } \\
\text { infrastructure (roads, factories, } \\
\text { workshops, houses) }\end{array}$ & 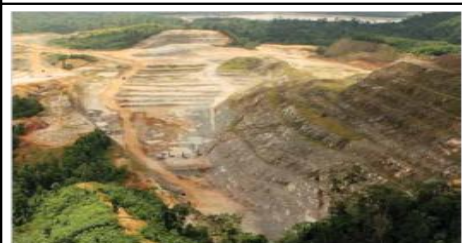 \\
\hline
\end{tabular}

To evaluate the performance of the classification algorithm, accuracies of the land cover/land use maps were assessed by using $30 \%$ of the sample class data generated for each satellite image. The accuracy assessment was conducted by creating confusion matrices between the land cover maps and the test data and calculating the overall 
accuracy, user accuracy, producer accuracy and the kappa statistic (Congalton, 1991). The kappa statistic was based on the formula provided by Congalton (1991), as shown in Equation (1).

$$
\mathrm{K}=\frac{N \sum_{i=1}^{r} x_{i i}-\sum_{i=1}^{r}\left(x_{i+} * x_{+i}\right)}{\mathrm{N}^{2}-\sum_{i=1}^{r}\left(x_{i+} * x_{+i}\right)}
$$

Where $\mathrm{K}$ is the kappa statistic, $\mathrm{N}$ is the total number of observations in the matrix, $\mathrm{r}$ is the number of rows, $x$ is the number of observations in row $i$ and column $\mathrm{i}, x_{+i}$ and $\mathrm{x}_{\mathrm{i}+}$ are the marginal totals of row $i$ and column $i$, respectively.

\section{Change Detection}

Land cover/land use change was detected using the post-classification comparison method. The land cover maps for 1986, 1991, 2002 and 2011, generated after image classification were reclassified and combined to form multiple bi-temporal land cover change maps for the periods 1986-1991, 1991-2002 and 2002-2011, using GIS spatial analysis. The areas and proportions of change from one thematic class to another (change matrix) between the periods and the annual rates of the changes, were computed to explain the magnitudes and directions of the land cover transitions within the three periods. Finally, the overall deforestation rates were determined, by merging evergreen and secondary forest classes in each period and calculating the proportion of changes per year, between the three periods, using the Food and Agriculural Organisation's (FAO) definition of forests (FAO, 2010). The change detection in this study is based on the assumption that land cover classes between 1986 and 2011 remained the same.

\section{Results}

The land cover/land use maps generated from image classification for 1986, 1991, 2002 and 2011 are presented in Figure 2, while the land cover proportions are shown in Table 3. The classification accuracies of the maps ranged between an overall accuracy of $90 \%, 80 \%, 88 \%$ and $78 \%$, while the Kappa statistic was $87 \%, 76 \%, 86 \%$ and $73 \%$ for the 1986, 1991, 2002 and the 2011 images, respectively. The Kappa statistics achieved in the land cover mapping are acceptable, according to the ranking by Landis and Koch (1977) and they are comparable to results of previous studies in the same study region (Kusimi, 2008; Schueler et al., 2011; Kumi-Boateng et al., 2012) and similar fragmented landscapes in West Africa (Braimoh and Vlek, 2005; Laurin et al., 2013). In Appendix A, the confusion matrices, showing how the accuracies were calculated, are presented.

Figure 2 and Table 3 show that the Bonsa catchment is covered by five broad land cover classes: evergreen forest, secondary forest, shrubs/farms, mining areas and settlements. The percentage of the water class, which is mainly water contained in tailings dams, is less than $0.2 \%$ of the study area. Overall, the areal coverage of evergreen forest and secondary forest have reduced between 1986 and 2011, while mining areas and settlements have increased substantially. Evergreen forest, the dominant land cover, occupied $68 \%$ of the catchment area in 1986, reduced to $62 \%$ in 1991 , decreased substantially again between 1991 and 2002 (50\%), after which it remained relatively 
constant (51\% for 2011). The results for the secondary forest class, however, were not consistent. The area under secondary forest increased from $27 \%$ in 1986 to $31 \%$ in 1991 , $35 \%$ in 2002 and decreased again to $19 \%$ in 2011 (Table 3). For the shrubs/farms class, the area increased consistently between 1986 and 2011. In 1986 the area under shrubs/farms was 5\% and it increased to 6\% in 1991, doubled in 2002 and more than quadrupled in 2011(Table 3). For the non-vegetative classes, the areal coverage increased substantially between 1986 and 2011. Settlement areas increased from $0.32 \%\left(4.8 \mathrm{~km}^{2}\right)$ in 1986 to $0.84 \%\left(12.4 \mathrm{~km}^{2}\right)$ in 1991 and remained almost the same for 2002 , but increased again in 2011 by $1.5 \%\left(22.4 \mathrm{~km}^{2}\right)$, while mining areas increased from $0.49 \%\left(7.2 \mathrm{~km}^{2}\right)$ in 1986 to $1.63 \%\left(24.2 \mathrm{~km}^{2}\right)$ in 2011 (Table 3).

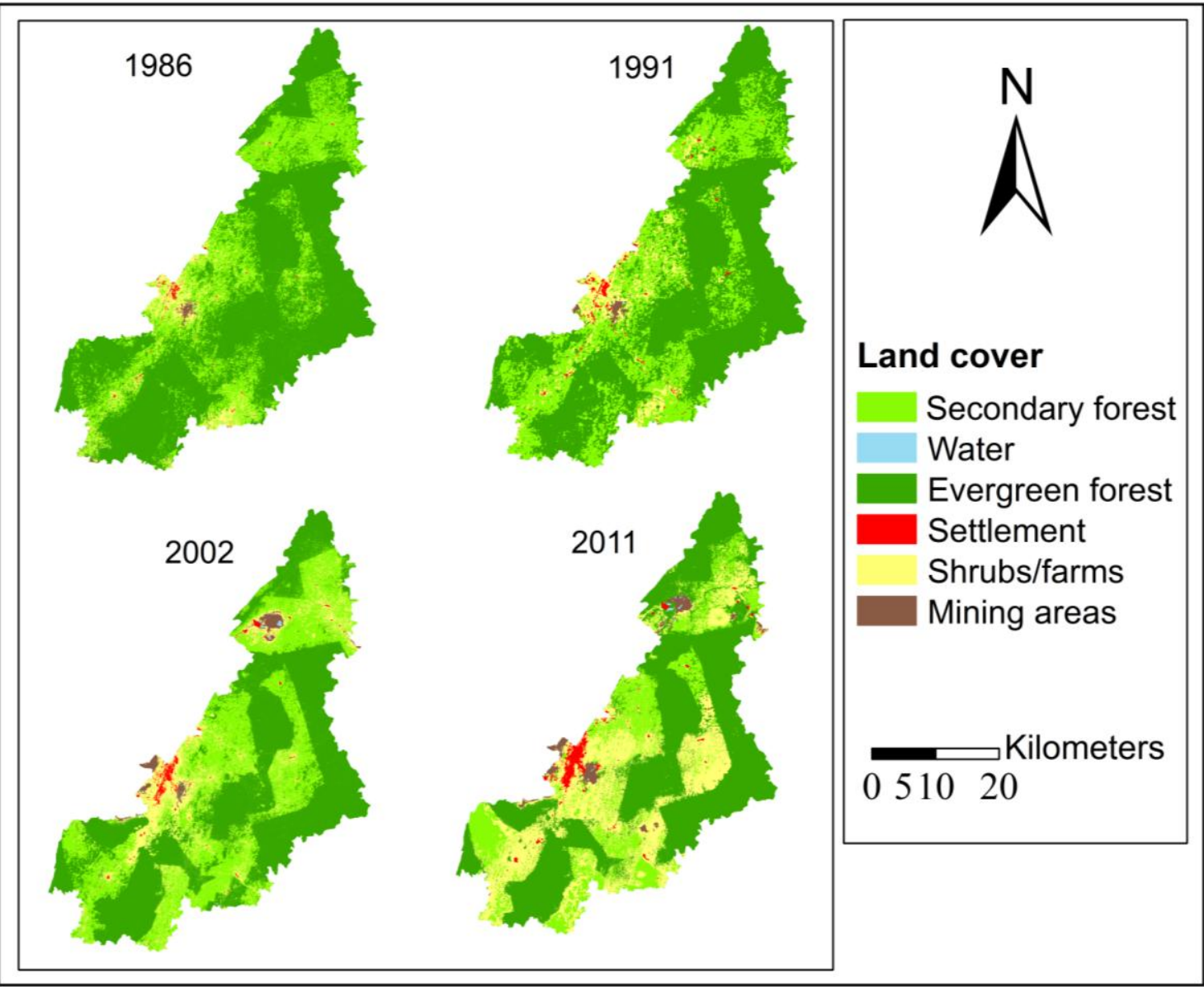

Figure 2. Land cover maps of 1986, 1991, 2002 and 2011

Table 3. Proportion of land cover between 1986 and 2011

\begin{tabular}{|c|c|c|c|c|c|c|c|c|}
\hline \multirow[b]{2}{*}{ Land cover } & \multicolumn{2}{|l|}{1986} & \multirow{2}{*}{$\begin{array}{r}1991 \\
\operatorname{area}\left(\mathrm{Km}^{2}\right)\end{array}$} & \multirow[b]{2}{*}{$\%$} & \multicolumn{2}{|l|}{2002} & \multicolumn{2}{|l|}{2011} \\
\hline & area $\left(\mathrm{Km}^{2}\right)$ & $\%$ & & & area $\left(\mathrm{Km}^{2}\right)$ & $\%$ & area $\left(\mathrm{Km}^{2}\right)$ & $\%$ \\
\hline Secondary forest & 393.8 & 26.6 & 457.3 & 30.8 & 523.7 & 35.3 & 280.3 & 18.9 \\
\hline Water & 0.9 & 0.1 & 0.2 & 0.0 & 1.9 & 0.1 & 1.4 & 0.1 \\
\hline Evergreen forest & 1003.2 & 67.7 & 916.5 & 61.8 & 744.0 & 50.2 & 754.6 & 50.9 \\
\hline Settlement & 4.8 & 0.3 & 12.4 & 0.8 & 12.6 & 0.8 & 22.4 & 1.5 \\
\hline Shrubs/farms & 72.4 & 4.9 & 90.0 & 6.1 & 180.1 & 12.1 & 399.4 & 26.9 \\
\hline Mining areas & 7.2 & 0.5 & 5.9 & 0.4 & 20.1 & 1.4 & 24.2 & 1.6 \\
\hline Total & 1482.3 & 100.0 & 1482.3 & 100.0 & 1482.3 & 100.0 & 1482.3 & 100.0 \\
\hline
\end{tabular}


The change matrices and the annualized rates of changes for 1986, 1991, 2002 and 2011 land cover/land use are presented in Table 4 and Figure 3, respectively. The change matrix illustrates the change in proportions of land cover from the initial year to the final year. The diagonal elements in the change matrix indicate areas of no change, while the off-diagonals show changes from one class to the other. Therefore, the sum of the diagonal elements represents the total area of land cover that did not change. The annualized rate of change shows the percentage of change in land cover area in a period divided by the number of years between the initial and the final year. Table 4 illustrates that between 1986 and 1991, 75\% $\left(1110 \mathrm{~km}^{2}\right)$ of the land cover did not change, compared to $67 \%\left(998 \mathrm{~km}^{2}\right)$ between 1991 and 2002 and $63 \%\left(933 \mathrm{~km}^{2}\right)$ between 2002 and 2011.

Table 4. Land cover/land use change matrices (\%)

\begin{tabular}{c|l|cccccc}
\hline \multicolumn{7}{c}{ (a) 1986-1991 } \\
\hline \multicolumn{1}{c}{ Land cover } & $\begin{array}{c}\text { Secondary } \\
\text { forest }\end{array}$ & Water & $\begin{array}{c}\text { Evergreen } \\
\text { forest }\end{array}$ & $\begin{array}{c}\text { Settlement } \\
\text { To } 1991\end{array}$ & $\begin{array}{c}\text { Shrubs/ } \\
\text { farms }\end{array}$ & $\begin{array}{c}\text { Mining } \\
\text { areas }\end{array}$ \\
\hline \multirow{5}{*}{} & Secondary & 16.9 & 0.0 & 11.7 & 0.0 & 2.1 & 0.1 \\
& forest & 0.0 & 0.0 & 0.0 & 0.0 & 0.0 & 0.0 \\
& Water & & & & & & \\
& Evergreen & 6.1 & 0.0 & 55.4 & 0.0 & 0.3 & 0.0 \\
& forest & 0.3 & 0.0 & 0.1 & 0.2 & 0.2 & 0.0 \\
& Settlement & 3.2 & 0.0 & 0.5 & 0.1 & 2.2 & 0.1 \\
& Shrubs/farms & 0.1 & 0.0 & 0.0 & 0.0 & 0.1 & 0.2 \\
\hline
\end{tabular}

(b) 1991-2002

\begin{tabular}{|c|c|c|c|c|c|c|c|}
\hline & & \multicolumn{6}{|c|}{ From 1991} \\
\hline & Land cover & $\begin{array}{l}\text { Secondary } \\
\text { forest }\end{array}$ & Water & $\begin{array}{c}\text { Evergreen } \\
\text { forest }\end{array}$ & Settlement & $\begin{array}{c}\text { Shrubs/ } \\
\text { farms }\end{array}$ & $\begin{array}{c}\text { Mining } \\
\text { areas }\end{array}$ \\
\hline \multirow{6}{*}{ To 2002} & $\begin{array}{l}\text { Secondary } \\
\text { forest }\end{array}$ & 19.1 & 0.0 & 13.5 & 0.2 & 2.5 & 0.0 \\
\hline & Water & 0.1 & 0.0 & 0.0 & 0.0 & 0.0 & 0.0 \\
\hline & $\begin{array}{l}\text { Evergreen } \\
\text { forest }\end{array}$ & 4.9 & 0.0 & 45.1 & 0.0 & 0.2 & 0.0 \\
\hline & Settlement & 0.2 & 0.0 & 0.0 & 0.3 & 0.4 & 0.0 \\
\hline & Shrubs/farms & 6.1 & 0.0 & 2.9 & 0.3 & 2.6 & 0.2 \\
\hline & Mining areas & 0.5 & 0.0 & 0.2 & 0.1 & 0.4 & 0.2 \\
\hline
\end{tabular}

(c) $2002-2011$

\begin{tabular}{|c|c|c|c|c|c|c|c|}
\hline & & \multicolumn{6}{|c|}{ From 2002} \\
\hline & Land cover & $\begin{array}{c}\text { Secondary } \\
\text { forest }\end{array}$ & Water & $\begin{array}{c}\text { Evergreen } \\
\text { forest }\end{array}$ & Settlement & $\begin{array}{c}\text { Shrubs/ } \\
\text { farms }\end{array}$ & $\begin{array}{c}\text { Mining } \\
\text { areas }\end{array}$ \\
\hline \multirow{6}{*}{ To 2011} & $\begin{array}{l}\text { Secondary } \\
\text { forest }\end{array}$ & 12.9 & 0.0 & 3.5 & 0.0 & 2.4 & 0.1 \\
\hline & Water & 0.0 & 0.0 & 0.0 & 0.0 & 0.0 & 0.1 \\
\hline & $\begin{array}{l}\text { Evergreen } \\
\text { forest }\end{array}$ & 6.5 & 0.0 & 42.2 & 0.0 & 2.0 & 0.2 \\
\hline & Settlement & 0.1 & 0.0 & 0.0 & 0.6 & 0.8 & 0.0 \\
\hline & Shrubs/farms & 15.7 & 0.0 & 4.5 & 0.1 & 6.4 & 0.2 \\
\hline & Mining areas & 0.2 & 0.1 & 0.1 & 0.0 & 0.5 & 0.8 \\
\hline
\end{tabular}




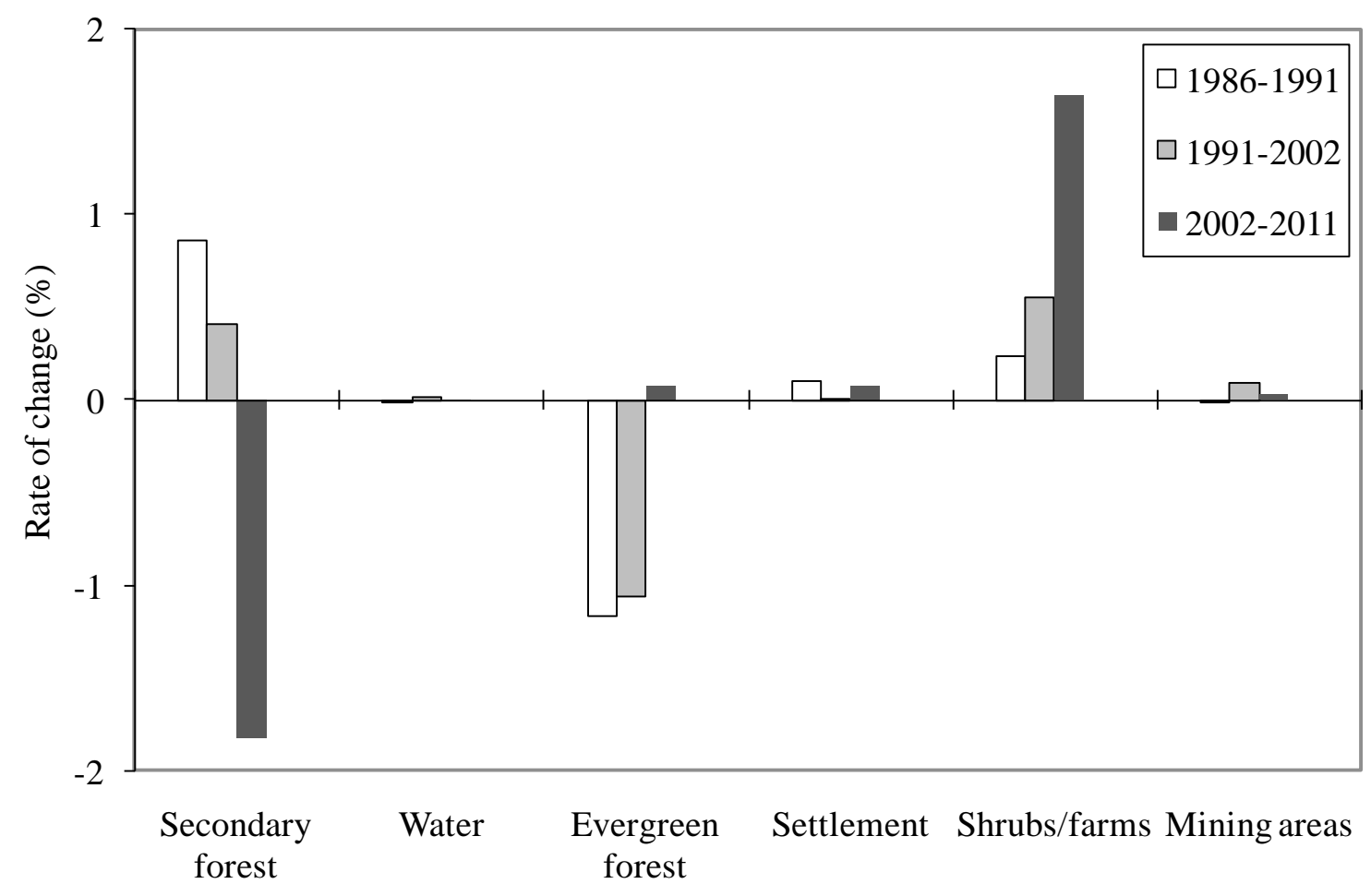

Figure 3. Annual rate of land cover changes

Table 4 further shows that transition from evergreen forest to secondary forest was higher between 1986 to 1991 (11.7\%) and between 1991 and 2002 (13.5\%) than between 2002 and 2011 (3.5\%), while transition from secondary forests to shrubs/farms was higher (16\%) between 2002 and 2011 than the other periods: i.e $3 \%$ between 1986 and 1991 and 6\% between 1991 and 2002. The transition from evergreen to secondary forest occurred with an annual rate of reduction of $1.2 \%$ between 1986 and 1991 and 1.1\% between 1991 and 2002, but during the period 2002-2011, the transition to secondary forest stopped (Figure 3). During the period 2002-2011, transition from secondary forest to shrubs/farms occurred, with the highest annual rate $(1.8 \%)$ of reduction in secondary forest, confirming an overall reduction in secondary forest (Figure 3). Using FAO's definition of forests (FAO, 2010), the evergreen and secondary forest areas (Table 3) were merged into one class. Therefore, annual deforestation in the Bonsa catchment, defined as the overall conversion of forest areas to other land cover types per year, ranged from $0.3 \%$ between 1986 and 1991, 0.7\% between 1991 and 2002 and 2\% between 2002 and 2011(Table 5).

Table 5. Annual deforestation rates for Bonsa catchment

\begin{tabular}{lrrr}
\hline Period & change in area & $\%$ change (total change) & \% change (annual) \\
\hline $1986-1991$ & -23.3 & -1.7 & -0.3 \\
$1991-2002$ & -106.0 & -7.7 & -0.7 \\
$2002-2011$ & -232.8 & -18.4 & -2.0 \\
\hline
\end{tabular}


Table 4 also demonstrates that forest recovery in the Bonsa catchment occurred from the re-growth of shrubs/farms and secondary forests. The re-growth from secondary forest to evergreen forest was similar for all the periods: i.e 6\% between 1986 and 1991, 5\% between 1991 and 2002 and 7\% between 2002 and 2011. Re-growth from shrubs/farms to secondary forest was also similar for the three periods: i.e $2 \%$ between 1986 and 1991, 3\% between 1991 and 2002 and 2\% between 2002 and 2011. However, the re-growth between 2002 and 2011 is marginally higher than the other two periods.

\section{Discussion}

\section{Land Cover and the Drivers of Changes}

The results of the study indicate that deforestation in the Bonsa catchment is widespread, confirming the previous land cover study by Kusimi (2008). The present study shows that between 1986 and 2011, evergreen forest and secondary forest reduced by $25 \%$ and $28 \%$, respectively, while mining areas increased over two-fold and settlements and shrubs/farms increased more than three and four-fold, respectively (Table 3). The increasing deforestation rate $(0.3 \%$ per year between 1986 and 1991, 0.7\% per year between 1991 and 2002 and 2\% per year between 2002 and 2011), recorded in this study (Table 5), is consistent with the $2 \%$ per year deforestation rate for Ghana, estimated by the FAO (2010), which is also consistent with trends in deforestation in Africa between 1990 and 2000 (1.1 million ha) and between 2000 and 2005 (2.7 million ha) (FAO and JRC, 2012). The results further show that, although the deforestation rate has been increasing with time, more than $50 \%$ of the land cover in the Bonsa catchment remained unchanged between 1986 and 2011. Evergreen forest represented the largest stable class $(55 \%$ between 1986 and 1991, 45\% between 1991 and 2002 and 42\% between 2002 and 2011), while secondary forest and shrubs/farm were the most fragmented classes (Table 4). The recorded land cover changes indicate that some areas which were originally covered by either evergreen forests or secondary forests have been converted to other cover types, and the recovery of the original vegetation (reforestation) during the three periods is small, compared to the overall deforestation.

The land cover/use changes in the Bonsa catchment can be attributed to anthropogenic drivers, which can be grouped into two broad categories, namely global and local factors. The global factors include globalization of agriculture, urbanization, international trade regimes and global politics, while the local factors include population growth, urbanization, immigration, economic development and government policy (Sage, 1994; Barbier, 2000; Meyfroidt et al., 2013). The recorded deforestation in the Bonsa catchment was influenced by local population growth (Ghana Statistical Service, 2005; Kusimi, 2008; Ghana Statistical Service, 2013), agricultural extensification (Kusimi, 2008; Sutton and Kpentey, 2012), timber logging (Asante, 2005; Kusimi, 2008) and increased surface mining activities (Akabzaa and Darimani, 2001) since 1986, when the implementation of the structural adjustment programme of the World Bank, liberalized Ghana's economy (Barbier, 2000) and increased foreign direct investment in the mining, timber and agricultural industries. Kusimi (2008) provided a discussion on how these driving forces have influenced land use changes within and around the Bonsa catchment.

In addition, population growth and per capita income are the two main drivers of settlement expansion (Sage, 1994). As the number of people in a community increases, 
there is the need to provide social infrastructure in transportation, housing, sanitation, health, education and recreation, which are mostly built on agricultural or forested lands. Hence, increases in a country's Gross Domestic Product (GDP), which result in higher per capita incomes, coupled with higher population growth rates, can lead to higher urbanization rates. In the Western region of Ghana, where the Bonsa catchment is located, the total urban population increased from $22.6 \%$ in 1984 to $42.4 \%$ in 2010 (Ghana Statistical Service, 2013) and correlates well with the expansion of settlements, recorded in this study, and is not surprising, considering that Ghana's GDP has increased from $\$ 8$ billion in 1984 to $\$ 32$ billion in 2010 (Kwakye, 2012). Therefore, for settlements, especially in the Tarkwa urban area, three main drivers namely (i) population growth (both natural growth and immigration), (ii) increase in per capita income and (iii) increases in mining activities, jointly influenced its expansion. According to Kusimi (2008) mining influenced population growth and urbanization by attracting people from other towns and cities in search of mining-based jobs The expansion of settlements, puts further pressure on the surrounding rural areas to produce more food to feed urban dwellers and more cash crops to pay for the importation of foreign products, which are associated with urban populations (Sage, 1994). The increased demand from urban settlements further causes the conversion of more forested lands into food and cash crop farms, thereby increasing the rates of deforestation. International trade and rising per capita incomes of the developed world and the ermerging markets, also reinforces deforestation in the developing world through higher demands for natural resources and commodities (Sage, 1994; Meyfroidt et al., 2013). This phenomenon, which results in volatility in prices of commodities such as, cocoa, rubber and gold, has also influenced deforestation in the Bonsa catchment.

Despite the increasing deforestation rate, the results of the study also indicate that concurrent vegetation regeneration is taking place in the Bonsa catchment. Vegetation regeneration occurred mainly because of programmes implemented by the Forestry Commission of Ghana, as well as some mining companies, maturing of rubber trees and the restrictions placed on the timber industry; banning exportation of round logs (Sutton and Kpentey, 2012) and the criminalization of chainsaw operations. The Forestry Commission of Ghana embarked on reforestation programmes in 2000 to reforest about $4000 \mathrm{~km}^{2}$ of degraded forests, at a rate of $200 \mathrm{~km}^{2} /$ year (FAO, 2010), but had only replaced $25 \mathrm{~km}^{2} /$ year by 2012 (Sutton and Kpentey, 2012). Mining companies in the Bonsa catchment have also carried out limited reforestation programmes in mined out areas (Tetteh, 2010). However, the results of this study show that, compared to deforestation, vegetation regeneration is less significant in the Bonsa catchment.

Anthropogenic land cover changes are caused by both proximate and global drivers, while the impacts are largely felt at the local scale. Therefore, in addition to mapping and identifying the drivers of the changes, there is also the need to identify the potential impacts of any changes in land use, in order to plan and manage land use effectively. Thus, the remainder of the discussion is focused on identifying the potential impacts of land cover/land use changes and discussing the need for further research.

\section{Potential Impacts of the Land Cover Changes}

The impacts of land cover changes can have substantial socio-economic, environmental and health impacts on communities, especially in poor countries. The impacts include change in hydrological regimes, reduced biodiversity, reduced soil organic carbon leading to poor fertility, pollution of surface and groundwater and 
changes in the albedo and the microclimate (Meyer and Turner II, 1994) and the invasion by alien species. Other impacts include emission of atmospheric trace gases (Penner, 1994), which contribute to climate changes. Impacts on hydrology and water resources are one of the most significant impacts of land cover changes. Land cover changes have impacts on water flows through changes in the partitioning of rainfall into the components of the hydrological cycle (Costa et al., 2003; D'Orgeval and Polcher, 2008). Land cover changes that increases imperviousness, such as surface mining and urbanization for example, reduce infiltration and increase the velocity and volumes of runoff, which can lead to floods, soil erosion and sedimentation, and pollution of rivers. Reduced infiltration can also lead to less groundwater recharge and less baseflows and drying of rivers, during low flow periods (Rogers, 1994; Randolph, 2012). Therefore, in the long-term, as population size and water use in the Bonsa catchment increases, if land cover changes are not controlled, deforestation and urbanization, could further lead to scarcity of water (Rogers, 1994).

Additionally, conversion of more forested lands to agriculture can increase soil erosion and loss of soil fertility, thereby making it more difficult to produce enough food and cash crops to meet the demands of the growing population in Bonsa catchment. Land degradation and the loss of soil fertility has the potential to reinforce more land cover changes through the extensification of agriculture (Barbier, 2000). Since agriculture in the Bonsa catchment is of the low-input type, the only means to increase production will be to increase the area under cultivation, which can further cause changes in land cover. Soil erosion, as well as the use of fertilizers and other chemicals, can also cause pollution of water bodies, destroy aquatic habitats and reduce aquatic biodiversity, if proper agricultural practices are not adopted. The removal of forests, also leads to loss of indigenous plant species, the destruction of animal habitats and reduction in biodiversity of the forest ecosystem. Planting rubber trees and other non-native tree species for example, can reduce groundwater recharge and baseflows significantly, because exotic plants consume more water than the native species.

Apart from deforestation and soil erosion, mining activities in the Bonsa catchment have the potential to cause heavy metal pollution of the water sources and increases in respiratory diseases, caused by dust pollution, resulting from blasting of rocks and movement of heavy duty mining equipment. Akabzaa et al. (2009) concluded that heavy metals, such as mercury, copper and nickel of concentrations above World Health Organisation (WHO) maximum allowable limits for drinking water, have been released into streams and groundwater systems by mines within the Ankobra basin. Similarly, Armah et al. (2012), concluded that the pH, COD and turbidity levels of groundwater in the Tarkwa minng area are above WHO standards. Further, between 1998 and 2006, eigth (8) spillages of cynanide were reported in the Tarkwa area (Tsuma, 2009). Impacts of both urbanization and surface mining also include changes in land surface albedo and the microclimate, which can create urban heat islands (UHI). UHI can cause skin cancer, as well as result in increased energy consumption of buildings. UHI is a phenomenon that results in higher temperatures in urban areas than the surrounding rural areas (Jensen, 2000), which is due to the presence of less vegetation/heat absorbing surfaces in urban/bare land areas.

According to Klocking and Haberlandt (2002), it is difficult to draw generalised, quantitative conclusions about impacts of land cover/use changes, without a specific 
local study. For example, Mahe et al. (2005), Boulain et al. (2009) and Warburton et al. (2012) among others, showed that the hydrological responses to land cover changes, depend on the scale of the changes, the land cover type, the climate and the location of the changes within a catchment. It is therefore imperative that locally relevant studies, consistent with the objectives of planning and development, within a specific basin, are undertaken.

\section{Further Research}

The population of people living in urban areas around the world is expected to grow from 3.15 billion in 2008 to 7.2 billion by 2050 (Randolph, 2012). The population pressure will make it difficult to provide services to people living in urban areas and many people in the developing world will not have access to portable water, sanitation and safe living environments, as urbanization increases. It is estimated that half of the people living in the developing world lack access to these services already (Randolph, 2012). The increasing rate of deforestation in Africa (FAO and JRC, 2012) for example, will have negative impacts on the livelihoods of people, who primarily depend on the natural resources for their development, while the goods and services provided by the natural environment will be reduced. The need to therefore plan and manage land use and water resources effectively in Africa and the rest of the developing world cannot be overemphasized.

In addition to the current land cover/land use changes, in the near future, the population of the Bonsa catchment in Ghana, is expected to grow at an average of $2 \%$ per annum (Ghana Statistical Service, 2005), mining activities will be intensified, as more mining leases are approved (Figure 4). Urbanization will also increase, as a result of both natural population increase and immigration to mining towns, and deforestation will increase. Therefore, in order to carryout effective land use planning, the impacts of both the current and the potential future land cover changes need to be quantified. Unfortunately, few studies of this type have been carried out and of these studies, all focus on impacts of surface mining on either groundwater pollution or surface water pollution (Kortatsi, 2003; Akabzaa et al., 2009; Armah et al., 2012), and airborne particulate matter pollution (Bansah and Amegbey, 2012). Although previous studies have mapped land cover changes between 1986 and 2002 of different sections of the catchment (Kusimi, 2008; Schueler et al., 2011; Kumi-Boateng et al., 2012), none assessed the impacts on the environment. The land cover change impacts on the hydrological flows, biodiversity and soil fertility are not known. Quantifying these impacts will provide the necessary information to protect life and property, protect the environment and ensure sustainable utilization of the natural resources of the catchment. In evaluating the impacts, the derived land cover information, as well as projected changes in the land cover, will be key variables. The potential drivers, identified in this study, will be vital in projecting future changes in the land cover. Therefore, further research will need to focus on modelling future changes in the land cover and quantification of the impacts of both historical and potential future changes in land cover on hydrology of Bonsa catchment. Additionally, future research will need to assess the impacts of climate change and land cover changes jointly. 


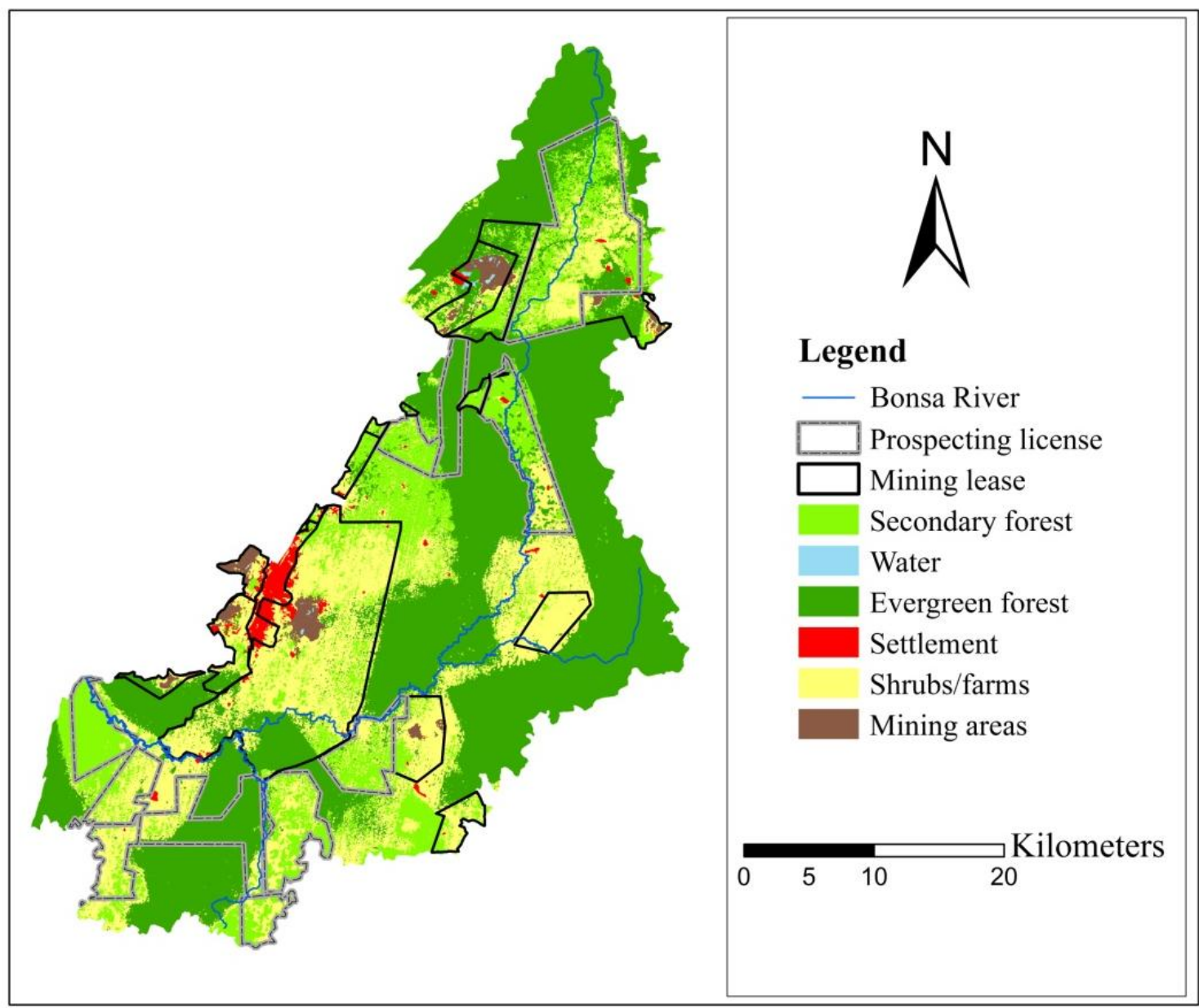

Figure 4. Land cover (2011) and approved mining leases and prospecting lincenses in the Bonsa catchment. Source : documents from mining companies (Bourke et al., 2007; Gold Fields Limited, 2012b, a; Castle Peak Mining Ltd, 2013).

\section{Conclusion}

Land cover mapping and change detection for the Bonsa catchment was executed successfully with Kappa statistics ranging between 72 and $87 \%$, using the maximum likelihood classification algorithm. The study has generated multi-temporal land cover data from 1986 to 2011, which shows that the Bonsa catchment is predominantly covered by forests, which are currently reducing at the rate of $2 \%$ per year, implying that the ongoing re-afforestation programmes undertaken by stakeholders in the catchment is occurring at a lower rate, compared to the deforestation. The study further indicates that the potential drivers of the land cover changes are both local and global, which include international trade, local population growth, agriculture extensification and urbanization. The study highlights the value of a multi-temporal land cover mapping approach to provide data to guide effective land use planning and water resources management, especially in data poor regions.

Acknowledgements. The authors wish to thank the Universities of KwaZulu Natal ( South Africa) and Mines and Technology (Ghana) for proving financial support to the correspomdng author for this research. Thanks also go to the United States Geological Survey (USGS) for providing the Landsat 
images through their GLOVIS database and the European Space Agency (ESA) for providing the third party mission (TPM) data, ALOS AVNIR-2 images through a Category 1 proposal (C1P14198). Edited by Mrs. Sharon Rees.

\section{REFERENCES}

[1] Abuelgasim, A.A., Ross, W.D., Gopal, S., Woodcock, C.E. (1999): Change Detection Using Adaptive Fuzzy Neural Networks: Environmental Damage Assessment after the Gulf War. - Remote Sensing of Environment 70:208-223.

[2] Aduah, M.S., Aabeyir, R. (2012): Land Cover Dynamics in Wa Municipality, Upper West Region of Ghana. - Research Journal of Environmental and Earth Sciences 4:658664.

[3] Akabzaa, T., Darimani, D. (2001): Impact of Mining Sector Investment in Ghana: A Study of the Tarkwa Mining Region - draft report, . SAPRIN.

[4] Akabzaa, T.M., Jamieson, H.E., Jorgenson, N., Nyame, K. (2009): The Combined Impact of Mine Drainage in the Ankobra River Basin, SW Ghana. - Mine Water and the Environment 28:50-64.

[5] Armah, F.A., Luginaah, I., Ason, B. (2012): Water Quality Index in the Tarkwa Gold Mining Area in Ghana. - The Journal of Transdisciplinary Environmental Studies (TES) 11:1-15.

[6] Asante, M.S. (2005): Deforestation in Ghana: Explainining the chronic failure of forest preservation policies in a developing Country - University Press of America, Maryland, USA.

[7] Atkinson, P.M., Tatnall, A.R.L. (1997): Introduction Neural networks in remote sensing. - International Journal of Remote Sensing 18:699-709.

[8] Bansah, K.J., Amegbey, N. (2012): Ambient Particulate Matter Monitoring - A Case Study at Tarkwa. - Research Journal of Environmental and Earth Sciences 4:419-423.

[9] Barbier, E.B. (2000): Links between economic liberalization and rural resource degradation in the developing regions. - Agricultural Economics 23:299-310.

[10] Boulain, N., Cappelaere, B., Séguis, L., Favreau, G., Gignoux, J. (2009): Water balance and vegetation change in the Sahel: A case study at the watershed scale with an ecohydrological model. - Journal of Arid Environments 73:1125-1135.

[11] Bourke, P., Arthur, J., Marshall, N., MacIntyre, J., Wasel, S.M., Urbaez, E. (2007): Technical Report, First time disclosure of mineral reserves, Hwini-Butre and Benso properties, Southwest Ghana. - Golden Star Resources Ltd, Denver, Colorado, USA.

[12] Braimoh, A.K., Vlek, P.L.G. (2004): Land-Cover Change Analyses in the Volta Basin of Ghana. - Earth Interactions 8:1-17.

[13] Braimoh, A.K., Vlek, P.L.G. (2005): Land-cover change trajectories in Northern Ghana. - Environmental Management 36:356-373.

[14] Campbell, J.B. (2002): Introduction to Remote Sensing - Taylor and Francis, London, United Kingdom.

[15] Castle Peak Mining Ltd. (2013): Strategic Gold Project in Ghana's Ashanti Belt, Apankrah Deposit Next Steps [Online]. - Castle Peak Mining Ltd., Vancouver, BC,Canada: Available:http://edg1.precisionir.com/companyspotlight/NA019419/CAPPresentation_Nov2013.pdf [Accessed 9 April 2014].

[16] Cohen, B. (2004): Urban Growth in Developing Countries: A Review of Current Trends and a Caution Regarding Existing Forecasts. - World Development 32:23-51.

[17] Congalton, R.G. (1991): A review of Assessing the Accuracy of Classification of Remotely Sensed Data. - Remote Sensing of Environment 37:35-46.

[18] Coppin, P., Jonckheere, I., Nackaerts, K., Muys, B., Lambin, E. (2004): Digital change detection methods in ecosystem monitoring: a review. - International Journal of Remote Sensing 25:1565-1596. 
[19] Costa, M.H., Botta, A., Cardille, J.A. (2003): Effects of large-scale changes in land cover on the discharge of the Tocantins River, Southeastern Amazonia. - Journal of Hydrology 283:206-217.

[20] D'Orgeval, T., Polcher, J. (2008): Impacts of precipitation events and land-use changes on West African river discharges during the years 1951-2000. - Climate Dynamics 31:249262.

[21] Dwomo, O., Dedzoe, C.D. (2010): Oxisol (ferralsol) development in two agro-ecological zones of Ghana: A preliminary evaluation of some profiles. - Journal of Science and Technology, Kwame Nkrumah University of Science and Technology (KNUST) 30:1128.

[22] FAO (2010): Global Forest Resources Assessment 2010, Country Report, Ghana. - In: Affum-Baffoe, K (ed.) Food and Agricultural Organisation (FAO), Rome, Italy.

[23] FAO and JRC (2012): Global forest land - use change 1990 - 2005. - In: Lindquist, E.J., D'annunzio, R., Gerrand, A., Macdicken, K., Achard, F., Beuchle, R., Brink, A., Eva, H.D., Mayaux, P., San-Miguel-Ayanz, J., Stibig, H-J. (eds.) FAO Forestry Paper No. 169. Food and Agriculture Organization of the United Nations and European Commission Joint Research Centre, Rome, FAO.

[24] Foody, G.M. (2002): Status of land cover classification accuracy assessment. - Remote Sensing of Environment 80:185-201.

[25] Frazier, A.E., Wang, L. (2011): Characterizing spatial patterns of invasive species using sub-pixel classifications. - Remote Sensing of Environment 115:1997-2007.

[26] Geneletti, D., Gorte, B.G.H. (2003): A method for object-oriented land cover classification combining Landsat TM data and aerial photographs. - International Journal of Remote Sensing 24:1273-1286.

[27] Ghana Statistical Service. 2005. 2000 Population and Housing Census, Analysis of District Data and implications for Planning, Western Region, Ghana. - In: Twum-Baah, K.A., Kumekpor, T.K.B., Addae-Mensah, I. (eds.) Ghana Statistical Service, Accra, Ghana.

[28] Ghana Statistical Service. 2013. 2010 Population \& housing census, National analytical report. - In: Awusabo-Asare, K. (ed.) Ghana Statistical Service, Accra, Ghana.

[29] Gold Fields Limited (2012a): Damang Gold Mine, Technical Short Form Report. - Gold Fields Limited, South Africa.

[30] Gold Fields Limited (2012b): Tarkwa Gold Mine, Technical Short Form Report. - Gold Fields Limited, South Africa.

[31] $\mathrm{Hu}$, Q., Willson, G.D., Chen, X., Akyuz, A. (2005): Effects of climate and landcover change on stream discharge in the Ozark Highlands, USA. - Environmental Modeling \& Assessment 10:9-19.

[32] Huang, C., Davis, L.S., Townshend, J.R.G. (2002): An assessment of support vector machines for land cover classification. - International Journal of Remote Sensing 23:725749.

[33] Jensen, J.R. (2000): Remote Sensing of the Environment: an Earth Resource Perspective - Prentice-Hall, New Jersey, USA.

[34] Klocking, B., Haberlandt, U. (2002): Impact of land use changes on water dynamics-a case study in temperate meso and macroscale river basins. - Physics and Chemistry of the Earth 27:619-629.

[35] Kortatsi, B.K. (2003): Acidifcation of Groundwater and its Implication on Rural Water Supply in the Ankobra Basin, Ghana. - West African Journal of Applied Ecology 4:3547.

[36] Kumi-Boateng, B., Mireku-Gyimah, D., Duker, A.A. (2012): A Spatio-Temporal Based Estimation of Vegetation Changes in the Tarkwa Mining Area of Ghana. - Research Journal of Environmental and Earth Sciences 4:215-229.

[37] Kusimi, J.M. (2008): Assessing land use and land cover change in the Wassa West District of Ghana using remote sensing. - GeoJournal 71:249-259. 
[38] Kwakye, J.K. (2012): Ghana's middle-income reality check part I: The economic dimension. - The Institute of Economic Affairs (IEA), Accra, Ghana.

[39] Lambin, E.F., Ehrlich, D. (1997): Land-cover changes in sub-Saharan Africa (19821991): Application of a change index based on remotely sensed surface temperature and vegetation indices at a continental scale. - Remote Sensing of Environment 61:181-200.

[40] Lambin, E.F., Geist, H.J., Lepers, E. (2003): Dynamics of land-use and land-cover change in tropical regions. - Annual Review of Environment and Resources 28:205-241.

[41] Landis, J.R., Koch, G.G. (1977): The measurement of observer agreement for categorical data. Biometrics 33:159-174.

[42] Laurin, G.V., Liesenberg, V., Chen, Q., Guerriero, L., Del Frate, F., Bartolini, A., Coomes, D., Wilebore, B., Lindsell, J., Valentini, R. (2013): Optical and SAR sensor synergies for forest and land cover mapping in a tropical site in West Africa. International Journal of Applied Earth Observation and Geoinformation 21:7-16.

[43] Lu, D., Mausel, P., Brondizio, E., Moran, E. (2004): Change Detection Techniques. International Journal of Remote Sensing 25:2365 - 2407.

[44] Lu, D., Weng, Q. (2007): A survey of image classification methods and techniques for improving classification performance. - International Journal of Remote Sensing 28:823870.

[45] Mahe, G., Paturel, J.E., Servat, E., Conway, D., Dezetter, A. (2005): The impact of land use change on soil water holding capacity and river flow modelling in the Nakambe River, Burkina-Faso. - Journal of Hydrology 300:33-43.

[46] Meyer, W.B., Turner II, B.L. (1994): Changes in Land Use and Land Cover: A Global Perspective - Cambridge University Press, Cambridge, United Kingdom.

[47] Meyfroidt, P., Lambin, E.F., Erb, K-H., Hertel, T.W. (2013): Globalization of land use: distant drivers of land change and geographic displacement of land use. - Current Opinion in Environmental Sustainability 5:438-444.

[48] Narumalani, S., Hlady, J.T., Jensen, J.R. (2002): Information extraction from remotely sensed data - In: Bossler, J.D., Campbell, J.B., Mcmaster, R.B., Rizos, C. (eds.) Manual of Geospatial Science and Technology. First Edition ed. - Taylor and Francis, London, United Kingdom.

[49] Nichol, J.E., Wong, M.S., Corlett, R., Nichol, D.W. (2010): Assessing avian habitat fragmentation in urban areas of Hong Kong (Kowloon) at high spatial resolution using spectral unmixing. - Landscape and Urban Planning 95:54-60.

[50] Penner, J.E. (1994): Atmospheric Chemistry and Air Quality. - In: Meyer, W.B., Turner Ii, B.L. (eds.) Changes in Land Use and Land Cover: A Global Perspective, Cambridge University Press, Cambridge, United Kingdom.

[51] Platt, R.V., Rapoza, L. (2008): An evaluation of an object-oriented paradigm for land use/land cover classification. - Professional Geographer 60:87-100.

[52] Randolph, J. (2012): Environmental Land Use Planning and Management - Island Press, Washington, USA.

[53] Richards, J.A., Jia, X. (2006): Remote Sensing Digital Image Analysis, An Introduction Springer, Berlin Heidelberg, Germany.

[54] Rogers, P. (1994): Hydrology and Water Quality. - In: Meyer, W.B., Turner Ii, B.L. (eds.) Changes in Land Use and Land Cover: A Global Perspective, Cambridge University Press, Cambridge, United Kingdom.

[55] Sage, C. (1994): Population and Income. - In: Meyer, W.B., Turner Ii, B.L. (eds.) Changes in Land Use and Land Cover: A Global Perspective, Cambridge University Press, Cambridge, United Kingdom.

[56] Schueler, V., Kuemmerle, T., Schroeder, H. (2011): Impacts of Surface Gold Mining on Land Use Systems in Western Ghana. - Ambio 40:528-539.

[57] Song, C., Woodcock, C.E., Seto, K.C., Lenney, M.P., Macomber, S.A. (2001): Classification and Change Detection Using Landsat TM Data: When and How to Correct Atmospheric Effects? - Remote Sensing of Environment 75:230-244. 
[58] Stavrakoudis, D.G., Theocharis, J.B., Zalidis, G.C. (2011): A multistage genetic fuzzy classifier for land cover classification from satellite imagery. - Soft Computing 15:23552374.

[59] Suresh Babu, V., Viswanath, P. (2009): Rough-fuzzy weighted k-nearest leader classifier for large datasets. - Pattern Recognition 42:1719-1731.

[60] Sutton, J., Kpentey, B. (2012.):An enterprise map of Ghana - International Growth Centre, London, United Kingdom.

[61] Tetteh, E.N. (2010): Evaluation of land reclamation practices at Anglogold Ashanti, Iduapriem mine Ltd, Tarkwa. Unpublished MSc Thesis, Department of Agroforestry, Faculty of Renewable Natural Resources, Kwame Nkrumah University of science and technology, Kumasi,Ghana.

[62] Tsuma, W. (2009): Gold Mining in Ghana, Actors, Alliances and Power, LIT Verlag, Berlin, Germany.

[63] Van Coillie, F.M.B., Verbeke, L.P.C., De Wulf, R.R. (2007): Feature selection by genetic algorithms in object-based classification of IKONOS imagery for forest mapping in Flanders, Belgium. - Remote Sensing of Environment 110:476-487.

[64] Verhoeye, J., De Wulf, R. (2002): Land cover mapping at sub-pixel scales using linear optimization techniques. - Remote Sensing of Environment 79:96-104.

[65] Warburton, M.L., Schulze, R.E., Jewitt, G.P.W. (2012): Hydrological impacts of land use change in three diverse South African catchments. - Journal of Hydrology 414:118-135.

[66] Wasige, J.E., Groen, T.A., Smaling, E., Jetten, V. (2013): Monitoring basin-scale land cover changes in Kagera Basin of Lake Victoria using ancillary data and remote sensing. - International Journal of Applied Earth Observation and Geoinformation 21:32-42.

[67] Youngentob, K.N., Roberts, D.A., Held, A.A., Dennison, P.E., Jia, X., Lindenmayer, D.B. (2011): Mapping two Eucalyptus subgenera using multiple endmember spectral mixture analysis and continuum-removed imaging spectrometry data. - Remote Sensing of Environment 115:1115-1128.

\section{APPENDIX}

Appendix A. Confusion Matrices Appendix A1(a). Confusion Matrix for 1986 land cover map

\begin{tabular}{|c|l|c|c|c|c|c|c|c|}
\hline \multicolumn{1}{c|}{} & Land cover & $\begin{array}{l}\text { Secondary } \\
\text { forest }\end{array}$ & Water & $\begin{array}{l}\text { Evergreen } \\
\text { forest }\end{array}$ & Settlement & $\begin{array}{l}\text { Shrubs/ } \\
\text { farms }\end{array}$ & Mining area & Total \\
\cline { 2 - 9 } & $\begin{array}{l}\text { Secondary } \\
\text { forest }\end{array}$ & 32 & 0 & 1 & 0 & 0 & 0 & $\mathbf{3 3}$ \\
\cline { 2 - 10 } & Water & 0 & 29 & 0 & 0 & 0 & 0 & $\mathbf{2 9}$ \\
\cline { 2 - 9 } $\begin{array}{c}\text { Land cover } \\
\text { map }\end{array}$ & Evergreen forest & 2 & 0 & 52 & 0 & 0 & 0 & $\mathbf{5 4}$ \\
\cline { 2 - 9 } & Settlement & 0 & 0 & 0 & 35 & 2 & 8 & $\mathbf{4 5}$ \\
\cline { 2 - 9 } & Shrubs/farms & 1 & 0 & 0 & 1 & 33 & 2 & $\mathbf{3 7}$ \\
\cline { 2 - 9 } & Mining area & 2 & 0 & 0 & 4 & 1 & 27 & $\mathbf{3 4}$ \\
\cline { 2 - 9 } & Total & $\mathbf{3 7}$ & $\mathbf{2 9}$ & $\mathbf{5 3}$ & $\mathbf{4 0}$ & $\mathbf{3 6}$ & $\mathbf{3 7}$ & $\mathbf{2 3 2}$ \\
\hline
\end{tabular}

Overall accuracy $=$ $208 / 232 * 100 \%=89.66 \%$

\begin{tabular}{l} 
Land cover \\
\hline Secondary forest \\
Water \\
Evergreen forest \\
Settlement \\
Shrubs/farms \\
Mining area
\end{tabular}

kappa $=87.49 \%$

\begin{tabular}{ll} 
Producer's accuracy $(\%)$ \\
\hline $32 / 37=$ & 86.49 \\
$29 / 29=$ & 100.00 \\
$52 / 53=$ & 98.11 \\
$35 / 40=$ & 87.50 \\
$33 / 36=$ & 91.67 \\
$27 / 37=$ & 72.97
\end{tabular}

\begin{tabular}{ll}
\multicolumn{3}{l}{ User's accuracy $(\%)$} \\
\hline $32 / 33=$ & 96.97 \\
$29 / 29=$ & 100.00 \\
$52 / 54=$ & 96.30 \\
$35 / 45=$ & 77.78 \\
$33 / 37=$ & 89.19 \\
$27 / 37=$ & 79.41
\end{tabular}


Appendix A 1(b). Confusion Matrix for 1991 land cover map

\begin{tabular}{|c|l|c|c|c|c|c|c|c|}
\hline \multicolumn{1}{|c|}{} & Land cover & $\begin{array}{l}\text { Secondary } \\
\text { forest }\end{array}$ & Water & $\begin{array}{l}\text { Evergreen } \\
\text { forest }\end{array}$ & Settlement & $\begin{array}{l}\text { Shrubs/ } \\
\text { farms }\end{array}$ & Mining area & Total \\
\cline { 2 - 9 } & $\begin{array}{l}\text { Secondary } \\
\text { forest }\end{array}$ & 26 & 0 & 2 & 0 & 0 & 0 & $\mathbf{2 8}$ \\
\cline { 2 - 10 } $\begin{array}{c}1991 \\
\text { Land cover } \\
\text { map }\end{array}$ & Water & 0 & 27 & 0 & 0 & 0 & 1 & $\mathbf{2 8}$ \\
\cline { 2 - 10 } & Evergreen forest & 3 & 3 & 62 & 0 & 0 & 0 & $\mathbf{6 8}$ \\
\cline { 2 - 10 } & Settlement & 0 & 0 & 0 & 57 & 4 & 2 & $\mathbf{6 3}$ \\
\cline { 2 - 9 } & Shrubs/farms & 17 & 0 & 0 & 0 & 26 & 0 & $\mathbf{4 3}$ \\
\cline { 2 - 9 } & Mining area & 0 & 4 & 0 & 24 & 0 & 48 & $\mathbf{7 6}$ \\
\cline { 2 - 9 } & Total & $\mathbf{4 6}$ & $\mathbf{3 4}$ & $\mathbf{6 4}$ & $\mathbf{8 1}$ & $\mathbf{3 0}$ & $\mathbf{5 1}$ & $\mathbf{3 0 6}$ \\
\hline
\end{tabular}

Overall accuracy $=$

kappa $=76.09 \%$

$246 / 306 * 100 \%=80.39 \%$

Land cover

Secondary forest

Water

Evergreen forest

Settlement

Shrubs/farms

Mining area

\begin{tabular}{ll}
\multicolumn{2}{l}{ Producer's accuracy $(\%)$} \\
\hline $26 / 46=56.52$ \\
$27 / 34=79.41$ \\
$62 / 64=96.88$ \\
$57 / 81=70.37$ \\
$26 / 30=86.67$ \\
$48 / 51=94.12$
\end{tabular}

Producer's accuracy (\%)

User's accuracy (\%)

$26 / 28=92.86$

$27 / 28=96.43$

$62 / 68=91.18$

$57 / 63=90.48$

$26 / 43=60.47$

$48 / 76=63.16$

\section{Appendix A 1(c). Confusion Matrix for 2002 land cover map}

\begin{tabular}{|c|l|l|c|l|l|l|c|c|}
\hline \multirow{5}{*}{} & Land cover & $\begin{array}{l}\text { Secondary } \\
\text { forest }\end{array}$ & Water & $\begin{array}{l}\text { Evergreen } \\
\text { forest }\end{array}$ & Settlement & $\begin{array}{l}\text { Shrubs/ } \\
\text { farms }\end{array}$ & Mining area & Total \\
\cline { 2 - 10 } & $\begin{array}{l}\text { Secondary } \\
\text { forest }\end{array}$ & 64 & 0 & 1 & 0 & 0 & 0 & $\mathbf{6 5}$ \\
\cline { 2 - 10 } $\begin{array}{c}\text { Land cover } \\
\text { map }\end{array}$ & Water & 0 & 51 & 0 & 0 & 0 & 0 & $\mathbf{5 1}$ \\
\cline { 2 - 10 } & Evergreen forest & 11 & 1 & 61 & 0 & 0 & 0 & $\mathbf{7 3}$ \\
\cline { 2 - 10 } & Settlement & 0 & 0 & 0 & 70 & 1 & 6 & $\mathbf{7 7}$ \\
\cline { 2 - 10 } & Shrubs/farms & 19 & 0 & 0 & 0 & 46 & 0 & $\mathbf{6 5}$ \\
\cline { 2 - 10 } & Mining area & 0 & 3 & 0 & 2 & 5 & 73 & $\mathbf{8 3}$ \\
\cline { 2 - 10 } & Total & $\mathbf{9 4}$ & $\mathbf{5 5}$ & $\mathbf{6 2}$ & $\mathbf{7 2}$ & $\mathbf{5 2}$ & $\mathbf{7 9}$ & 414 \\
\hline
\end{tabular}

Overall accuracy $=$

$365 / 414 * 100 \%=88.16 \%$

Land cover

Secondary forest

Water

Evergreen forest

Settlement

Shrubs/farms

Mining area $\mathrm{kappa}=85.76 \%$

\begin{tabular}{ll} 
Producer's accuracy $(\%)$ \\
\hline $64 / 94=68.09$ \\
$51 / 55=92.73$ \\
$61 / 62=98.39$ \\
$70 / 72=97.22$ \\
$46 / 52=88.46$ \\
$73 / 79=92.41$
\end{tabular}

\begin{tabular}{ll}
\multicolumn{2}{l}{ User's accuracy $(\%)$} \\
\hline $64 / 65=$ & 98.46 \\
$51 / 51=$ & 100.00 \\
$61 / 73=$ & 83.56 \\
$70 / 77=$ & 90.91 \\
$46 / 65=$ & 70.77 \\
$73 / 83=$ & 87.95
\end{tabular}


Appendix A 1(d). Confusion Matrix for 2011 land cover map

\begin{tabular}{|c|c|c|c|c|c|c|c|c|}
\hline \multicolumn{9}{|c|}{ Reference Data (No. of points) } \\
\hline \multirow{8}{*}{$\begin{array}{c}2011 \\
\text { Land cover } \\
\text { map }\end{array}$} & Land cover & $\begin{array}{l}\text { Secondary } \\
\text { forest }\end{array}$ & Water & \begin{tabular}{|l|} 
Evergreen \\
forest
\end{tabular} & Settlement & $\begin{array}{l}\text { Shrubs/ } \\
\text { farms }\end{array}$ & Mining area & Total \\
\hline & $\begin{array}{l}\text { Secondary } \\
\text { forest }\end{array}$ & 44 & 0 & 0 & 0 & 2 & 0 & 46 \\
\hline & \begin{tabular}{|l|l|} 
Water \\
\end{tabular} & 0 & 36 & 0 & 4 & 0 & 0 & 40 \\
\hline & Evergreen forest & 6 & 0 & 34 & 0 & 12 & 0 & 52 \\
\hline & Settlement & 0 & 1 & 2 & 36 & 1 & 6 & 46 \\
\hline & Shrubs/farms & 26 & 0 & 1 & 0 & 67 & 0 & 94 \\
\hline & Mining area & 0 & 9 & 0 & 7 & 0 & 50 & 66 \\
\hline & Total & 76 & 46 & 37 & 47 & 82 & 56 & 344 \\
\hline
\end{tabular}

Overall accuracy $=$

kappa $=72.84 \%$

$267 / 344 * 100 \%=77.62 \%$

Land cover

Secondary forest

Water

Evergreen forest

Settlement

Shrubs/farms

Mining area
Producer's accuracy (\%)

44/77= 57.89

$36 / 46=78.26$

$34 / 37=91.89$

$36 / 47=\quad 76.60$

$67 / 82=81.71$

$50 / 56=\quad 89.29$
User's accuracy (\%)

$44 / 46=95.65$

$36 / 40=90.00$

$34 / 52=65.38$

$36 / 46=78.26$

$67 / 94=71.28$

$50 / 66=75.76$ 